\title{
ARQUEOLOGIA FUNERÁRIA E A FURNA DO ESTRAGO
}

\section{FUNERARY ARCHAEOLOGY AND THE FURNA DO ESTRAGO}

\author{
Sheila Mendonça de Souza ${ }^{1}$ \\ sferraz@ensp.fiocruz.br
}

\section{RESUMO}

O sítio arqueológico Furna do Estrago vem inspirando Teses, Dissertações, artigos sem que o tema tenha sido esgotado. A produção científica sobre o sítio está concentrada em abordagens do material biológico, principalmente esqueletos humanos provenientes do cemitério. Diferentes aspectos da cultura material, das estruturas funerárias e dos níveis arqueológicos proporcionariam informações a partir de novas técnicas e métodos que ajudariam a responder as questões arqueológicas remanescentes. Sítios arqueológicos funerários são especialmente ricos em interfaces bioculturais, sendo fonte quase inesgotável de investigações. Aqui revisitamos a arqueologia da Furna através da sua produção, lembrando algumas questões em aberto que poderiam ser tema de futuros estudos.

Palavras-chave: Revisão da literatura, Pernambuco, arqueologia funerária.

\footnotetext{
${ }^{1}$ Escola Nacional de Saúde Pública Sergio Arouca, Fiocruz, RJ.
} 


\begin{abstract}
Furna do Estrago archaeological site inspired Thesis, Dissertations and papers without being exhausted. The scientific production about that site is concentrated on biological materials, specially human skeletons from its cemetery. Different aspects of the material culture in the funerary structures and other archaeological levels could provide information based on new techniques and methods helping to answer remaining archaeological questions. Funerary archaeological sites provide rich biocultural connections so they are sources of infinite questions to be investigated. In the present paper we revisit Furna do Estrago through the related scientific production, reminding some questions still opened that could be theme for future research.
\end{abstract}

Keywords: Literature review, Pernambuco, funerary archaeology.

\title{
CONTEXTO DA PESQUISA
}

Quando os pictoglifos do modesto abrigo-sob-rocha denominado Furna do Estrago, localizado no Brejo da Madre de Deus, estado de Pernambuco, foram inicialmente noticiados por Marcos Albuquerque, da Universidade Federal de Pernambuco (Albuquerque, 1971), não se imaginava o que significaria aquele sítio, nem a quantidade de informação e conhecimento novo que ele poderia prover.

Revisitado e prospectado por Jeannette Maria Dias de Lima, então professora e pesquisadora da Universidade Católica de Pernambuco em 1982 (Lima, 1984), foi objeto de escavações sucessivas por ela, sendo tema de sua Dissertação de Mestrado e Tese de Doutorado, além de diversas publicações e comunicações em congressos. Para seu estudo Jeannette contou com apoio de diversos colegas, além de alunos e colegas do Laboratório de Arqueologia da UNICAP. Entre os 
profissionais que a apoiaram destacam-se Pedro Ignácio Schmitz, do Instituto Anchietano de Pesquisa da Universidade do Vale do Rio dos Sinos (Lima et al., 2012; Schmitz, 2014), a autora deste artigo e Marília Carvalho de Mello e Alvim, do Museu Nacional, entre outros, a maior parte deles registrados na literatura que contribuiu para o conhecimento daquele sítio arqueológico. Muitos dos autores de trabalhos sobre a Furna, realizados nos últimos 15 anos, entretanto, não conheceram Jeannette, mas dão seguimento ao seu legado.

Desvelado do ponto de vista arqueológico, o sítio surpreendeu pela profusão de materiais que proporcionou, materiais estes hoje musealizados. Este achado permitiu que fossem abertas diferentes linhas de investigação, tanto em campo como em laboratório, tratando-se ainda hoje de um dos sítios funerários com maior potencial de informação do Brasil. Aqui será feita uma revisita à Furna à produção científica sobre aquele sítio, e uma reflexão sobre porque os sítios arqueológicos em geral e os funerários em especial devem ser revisitados.

Dotado de grande potencial que ainda aguarda ser desenvolvido nos próximos anos, a Furna do Estrago, e principalmente seu conjunto de sepultamentos humanos, permitem ainda muitos estudos. Ainda que este cemitério corresponda a apenas um curto período de uso intensivo daquele local, foi sem dúvida um dos mais interessantes achados arqueológicos em décadas. Desde as primeiras escavações, sucessivos estudos bioarqueológicos e de restos vegetais e fauna passaram a ser feitos nos materiais ali recuperados, entre eles Mendonça de Souza 
(1995), Mendonça de Souza, Lima e Carvalho (1998), Mendes (2006), Sianto et al. (2012), Castro e Cisneros (2014), Teixeira-Santos et al. (2015) e muitos mais. Ainda assim, parte do conhecimento e ideias sobre este sítio, e seu uso também funerário, não chegou a ser explorada nos trabalhos subsequentes, ou não chegou a ser suficientemente divulgado ou publicada. Como consequência, algumas análises e interpretações sobre a Furna e/ou seu cemitério permanecem deslocadas, desconexas, ou contribuem menos do que deveriam para a arqueologia brasileira, e parte delas corre o risco de não creditar adequadamente autorias e descobertas.

Valorizado pelo registro datado de passagens humanas que remontam a cerca de onze mil anos atrás, a Furna ainda guarda potencial arqueológico, já que a maior parte dos trabalhos dedica-se ao cemitério. Por outro lado, após décadas de sua descoberta e escavação, avanços substantivos em métodos e técnicas permitem explorar novas questões, testar novas hipóteses e corrigir interpretações. Grande parte do desafio da arqueologia consiste em analisar o grande volume de materiais e dados acumulados pelas pesquisas de campo, e tal como vem sendo comprovado em projetos recentes, nem toda revisita de um sitio em campo deve voltar-se pás novas e extensivas escavações já que muito pode ser elucidado com abordagens estratégicas de áreas anteriormente escavadas (Gaspar e Mendonça de Souza, 2013), não apenas em sítios com conchas. 
$\mathrm{Na}$ Furna o foco principal do interesse até agora foi o cemitério, ainda que seu uso tenha sido de curta duração relativamente. Certamente foi o mais bem explorado nas pesquisas e publicações, mas infelizmente, confunde-se muitas vezes com o conjunto das ocupações do sítio, e na literatura nem sempre é clara a distinção sobre os diferentes usos do abrigo, transições, interrupções de uso do abrigo, etc. Ao descrever ligeiramente o sítio e sua antiguidade e passar a descrever o cemitério, nem sempre é claro o hiato temporal, e a necessidade de dissociar as diferentes "Furnas" de que os arqueólogos devem se ocupar, e também os confundimentos e dificuldades inerentes ao estudo arqueológico. No imaginário leigo, e mesmo no imaginário científico, observa-se certa confusão, agravada pelos esforços da multidisciplinaridade, infelizmente sempre mal sucedida como interdisciplinaridade que, se traz contribuições especializadas de diferentes áreas, dificulta o trânsito natural e fluido dos conceitos, detalhes, processos, informações.

A Furna, como outros sítios é complexo. Apresentando um componente funerário tão rico, exige ainda mais a convergência de diferentes especialistas e recursos para seu estudo. Assim foi no começo, longe do que seria uma escavação ideal. E assim prossegue, nos estudos dissociados dos itens arqueológicos, nos quais é evidente a dificuldade com que os dados se integram e o discurso sobre a Furna é construído.

Tal como descrito (Lima et al., 2012), as escavações do sítio cobriram uma área pequena, mas que havia sido utilizada no passado de maneira intensiva, e abordaram um solo arqueológico pouco compactado e entrecortado por sucessivos 
usos, e pela perturbação intensa das ocupações mais antigas, pela abertura de dezenas de covas funerárias, muitas delas sobrepostas, e pela ação antrópica recente. Estas condições do sítio somaram-se a impossibilidade de realizar-se pesquisas prolongadas garantidas por projetos robustos, e em local protegido de vandalismo e trânsito contemporâneo. Assim sendo, a primeira questão que vem a mente é se abordagens atuais poderiam favorecer nossa compreensão atual sobre o sítio Furna do Estrago como um todo.

O cemitério, por sua vez, representado pelo belíssimo conjunto de materiais funerários, explorado tanto de perspectivas culturais, como de perspectiva biológicas, ao longo de mais de três décadas, pode parecer bem explorado. Entretanto, muitos estudos limitam-se a apresentar resultados analíticos especializados, pouco dialogando com dados já produzidos para o sítio, e assim permanecendo pouco integrados. Assim, a proposição de novas questões e hipóteses sobre o grupo que utilizou a Furna como cemitério deve levar em conta o espaço existente para articular dados, além do potencial de análises dos diversos materiais a partir de novas tecnologias e perguntas. Lamentavelmente, a dificuldade em superar barreiras deste tipo tem grande impacto sobre a arqueologia, mas talvez se expresse de maneira mais severa em sítios funerários, tal como no caso do cemitério da Furna. Em casos como este é imprescindível ter mais do que convergência das expertises. É necessário o contínuo diálogo e reflexão desafiadora entre campos diversos, retroalimentação proporcionada por 
resultados compartilhados, fluxo de ideias e inquietações motivadoras de novas e desafiadoras abordagens interpretativas.

Mais do que o planejamento de uma pesquisa conjunta, é necessário que haja continuidade e afinidade entre especialistas envolvidos em objetos comuns de trabalho. Assim sendo, é mais que tudo um processo social e interativo, que hoje ganha definições distintas na burocracia acadêmica, por exemplo, no conceito de rede, ou no conceito de ciência aberta. No caso da Furna do Estrago, a oportunidade de manter durante as duas primeiras décadas de pesquisa uma associação continuada entre arqueólogos, antropólogos e bioarqueólogos permitiu convergir e integrar resultados, em um exercício avançado para o período. Ainda assim, sem que fosse possível esgotar o material e o tema, restam novas perguntas sobre o cemitério, que podem e devem ser formuladas. Revendo a literatura e revisitando dados ainda inéditos sobre a Furna do Estrago, será possível tentar contribuir um pouco mais para a identificação de lacunas no conhecimento acumulado sobre o cemitério, e sugerir hipóteses a serem testadas, já que muito do que foi feito anteriormente trilhou roteiros dedutivos. Tal como sugerido para o sítio como um todo, o cemitério, momento curto, porém rico, da ocupação humana naquele abrigo, ainda pode ser melhor estudado.

No presente volume, dedicado à arqueologia funerária, voltamos a visitar o cemitério, através da literatura sobre a Furna do Estrago. 
A arqueologia funerária vem progredindo em seu desenvolvimento no Brasil, como atestam entre outros os 12 trabalhos que enfocaram a Furna sob esta perspectiva e que estão aqui listados, além é claro dos trabalhos gerais sobre o sítio com ênfase em seu cemitério. No entanto, ainda que os projetos de bioarqueologia tenham se multiplicado no Brasil, e a abordagem de sítios com remanescentes humanos tenha podido ser cada vez mais técnica e sofisticada, tem sido evidente a necessidade de melhorar nossa capacidade de integração de equipes multidisciplinares que desenvolvam experiência específica neste tipo de testemunho. Projetos em sambaquis do sul e sudeste, também conhecidos pelos generosos cemitérios, vêm acumulando a experiência de equipes formadas por arqueólogos, bioarqueólogos e especialistas de outras áreas do conhecimento para o trabalho em torno de objetos comuns e esforços integrados em torno de um mesmo sítio ou cemitério. Limitações representadas pelo tempo disponível para preparação de projetos, descontinuidades no trabalho, e outros fatores como as prioridade e as propriedades, embora dificultem não tem impedido que se aperfeiçoem abordagens estratégicas em propostas/ projetos conjuntos, de modo a atender a lugares de deposição de mortos (Gaspar e Mendonça de Souza, 2013). Na região de Lagoa Santa, o trabalho continuado e integrado de arqueólogos e bioarqueólogos também vem permitido abordagens bem sucedidas em sítios como a Lapa do Santo e outros (Da-Gloria, 2015). Mas ainda é preciso criar condições melhores para que arqueólogos de perfil generalista passem a planejar suas abordagens específicas para sítios funerários, associando-se a bioarqueólogos desde a etapa de planejamento de seus projetos. 
No cemitério da Furna do Estrago, circunstâncias da época tornaram a bioarqueologia principalmente parceira em laboratório e no pós-escavação. Ainda que a interlocução continuada com os arqueólogos tenha permitido alimentar o campo com algumas ideias, não foi possível naquele momento exercer o preconizado para que o conceito de bioarqueologia fosse plenamente realizado. Em contrapartida, e pela primeira vez no Brasil, houve chance de estudar uma coorte grande e bem preservada de esqueletos humanos representando uma população natural, provavelmente abrangendo a quase totalidade de um cemitério, delimitada num recorte temporal bem definido e acompanhada de um rico conjunto de elementos culturais. Esta oportunidade permitiu análises e interpretações únicas. Ao mesmo tempo, estimulou um sem número de questões que só poderão ser investigadas se outra Furna semelhante puder ser escavada a partir de um projeto arqueológico/bioarqueológico.

Mas este sítio, excepcional, até agora único, aparentemente ainda não se reproduziu em outros achados, mesmo na região onde as condições ambientais e o povoamento humano teoricamente o permitiriam. Onde estarão as outras Furnas? A busca de uma melhor caracterização do sítio - que pode ser melhor conhecido e as condições que convergiram para que este testemunho fosse formado e preservado, talvez seja outro dos desafios que devem continuar a ser enfrentados. Dados que ainda não valorizamos ou associamos, novos dados, tecnologias novas poderão ajudar a prever e localizar outras Furnas? 
De volta ao cemitério, ao espaço funerário e aos materiais e ossos que dele foram retirados; ao debruçar-nos sobre a sua estratigrafia funerária desafiadora com tantos enterros em tão pouco espaço; às lacunas do registro arqueológico, confirmamos que ali, na perturbação e re-deposição recorrentes, estão guardadas pistas das transições e imbricações culturais e biológicas daquela ocupação. A estratigrafia de covas que cortam camadas, covas que cortam covas, materiais sobrepostos e mergulhados, perturbações e deposições, testemunham diacronias de eventos e processos naturais e antrópicos deve ser minuciosamente revisada. Registros de campo, arqueologia de imagens da época, notas nos diários, fichas e mapas oferecem indícios. As escolhas no espaço ocupado, distribuindo enterros e testemunhos, nos falam de relações e significados sociais, reforçados por objetos, mas também por evidências morfológicas no que restou dos próprios corpos humanos. As osteobiografias e a paleoepidemiologia dialogam com a diacronização dos enterros, abrindo janelas para entender o que se passou no período daquela ocupação. Plantas e bichos conversam com todas as dimensões do cemitério, e pedem mais diálogo. A Furna do Estrago, tal como outros sítios funerários já escavados, aguarda mais leituras, olhares para o que ainda não foi considerado, interpretado, descoberto, e cabe lembrar que parte dos dados e interpretações não chegaram a ser publicadas, mas podem estar presentes em documentos originais. 
No presente caso, embora a maior parte dos comentários e reflexões esteja apoiada na literatura, alguns deles baseiam-se em dados inéditos produzidos, por esta autora e Marílía Alvim, sempre em conversa com a própria Jeannette Lima. Com ambas e por anos foi possível dividir angústias sobre a Furna, e realizações profissionais. A morte de ambas certamente contribuiu para alguma descontinuidade nas pesquisas, ainda que o tema tenha sido revisitado por numerosos outros alunos e colegas, como a compilação da literatura deixa claro. Aqui, naturalmente, na citação do inédito será dado o devido crédito às ideias veiculadas apenas nos colégios invisíveis. ${ }^{2}$

\section{A FURNA REVISITADA A PARTIR DE JEANNETTE LIMA}

Em outubro de 1982, Jeannette Maria Dias de Lima, realizando sondagens no abrigo-sob-rocha denominado Furna do Estrago, localizado no município do Brejo da Madre de Deus, estado de Pernambuco, descobriu o que seriam os primeiros ossos humanos aparentemente desconexos (Lima, 1984). Uma escavação, meses mais tarde, iniciou a série de achados que conhecemos, e que proporcionou àquela arqueóloga sua dissertação de Mestrado, defendida na Universidade Federal de Pernambuco e orientada por Gabriela Martin. Uma etapa das escavações, levada a cabo em 1987, conta com a contribuição de Pedro Ignácio Schmitz e outros do Instituto Anchietano de Pesquisas. Desde então, diferentes especialistas e generalistas reportaram sobre a Furna, e em nossa compilação encontramos mais de 70 trabalhos entre publicações integrais e na forma de resumos, o que

\footnotetext{
${ }^{2}$ A estas amigas in memoriam também dedico esta visita à Furna do Estrago.
} 
certamente representa a maior parte, mas não a totalidade do que foi produzido. A maior quantidade de resultados, sem dúvida, refere-se ao conjunto denominado cemitério, ainda que este represente apenas algo entre 250 e 300 anos de uso do abrigo, que para além deste uso mostra evidências arqueológicas de ter sido ocupado por grande lapso de tempo, com passagens humanas iniciadas cerca de 11.000 anos atrás. Talvez por esta razão muitos não percebam claramente que o sítio - o todo - não deve ser tomado pela parte - o cemitério, e que a arqueologia funerária da Furna, seja até hoje muito melhor conhecida do que os outros aspectos do mesmo sítio.

Embora os primeiros achados tenham sido divulgados na dissertação de Mestrado de Jeannette Lima, a síntese final dos achados na Furna aguardou por longo tempo que ela concluísse seu doutoramento na Universidade Autônoma do México. Entretanto, quase terminada a Tese, a autora perdeu sua batalha pela saúde, e não conseguiu defende-la. Cerca de 10 anos depois, partes do seu manuscrito (Lima, 2001), associadas ao que já havia publicado em sua Dissertação de Mestrado (Lima, 1985c) para o mesmo sítio, foram compilados e reorganizados por Pedro Ignácio Schmitz, e revisado por Marcus Vinicius Beber e esta autora. Num volume ilustrado e póstumo de síntese do que escrevera a arqueóloga, foi finalmente disponibilizando à comunidade científica um conjunto de dados e interpretações que apresentavam o estado da arte dos produzido e incorporado por ela sobre a Furna do Estrago (Lima et al., 2012). 
$\mathrm{O}$ acervo arqueológico, daquele sítio está hoje dividido entre o Museu do Brejo da Madre de Deus, o Museu da Universidade Católica de Pernambuco e o Laboratório de Arqueologia da Universidade Católica de Pernambuco - Unicap. Foi possível compilar 14 Dissertações de Mestrado e 5 Teses de Doutorado, 30 artigos, 23 resumos e algumas monografias escritos em cerca de 35 anos desde que o sítio foi descoberto. Certamente muitos trabalhos que apenas mencionam o sitio e apresentam alguns dados em discussões de diferentes naturezas não se encontram compilados, e um número não estimado de comunicações em eventos não foram localizadas, mas o que está relacionado já mostra a importância de sistematizar esta produção.

A face do mais famoso esqueleto humano encontrado na Furna, o chamado "flautista", homem velho e impressionante, sepultado com uma flauta osso que ainda hoje é achado único no Brasil, foi recentemente reconstituído, trazendo-o de volta à mídia. Resultados da arqueologia da Furna, além de diferentes versões e visões locais e acadêmicas sobre o sítio estão hoje em sites institucionais, blogs, no youtube e em outros veículos da mídia eletrônica, com grande destaque como, por exemplo, o filme de Edmilson Ribeiro (https://www.youtube.com/watch?v=OmmdGGhEc18). Motivo de um sem número de notícias em veículos da mídia, este sítio, ao longo de mais de trinta anos, vem protagonizando a produção científica arqueológica e o contínuo interesse popular, estando hoje em lugar de destaque até no turismo regional. Ao cabo de tantos anos, e quase como se cumprisse um destino, a Furna foi tema da 
Dissertação de Mestrado em Gestão Pública da Universidade Federal de Pernambuco, feita por outra Lima, a Ana Patrício (Lima, 2006). Após analisar o sítio e o Brejo, propôs um projeto turístico tendo ao centro a Furna do Estrago, articulada a roteiros e um ecomuseu local, tornando a arqueologia regional um atrativo de gestão moderna e organizada. Desta forma, a Furna, além de toda a contribuição científica que proporcionou à arqueologia do país, apresentou-se pronta a realizar também aquilo que Jeannette Lima defendia como pioneira no Brasil: a arqueologia e o turismo lado a lado. Nesse mesmo sentido, um Decreto $\left(n^{\circ} 16,2003\right)$ editado pelo Município do Brejo da Madre de Deus já havia declarado o sítio de utilidade pública e interesse social, desapropriando o que se chamou "cemitério dos índios", no intuito de assegurar sua preservação.

Ainda que o material arqueológico e os dados obtidos nas escavações da Furna tenham permitido um número elevado de pesquisas, o fato de numerosos resultados terem sido publicados apenas em resumos, ou comunicados verbalmente, torna parte do conhecimento indisponível para a consulta pela geração atual. Entre as publicações integrais disponíveis, há exemplos de publicações internacionais extremamente especializadas, como os de paleogenética (Santos et al., 1996) ou paleopalinologia (Teixeira-Santos et al., 2015). Alguns artigos, por sua vez, embora publicados em periódicos nacionais, podem não se encontrar facilmente acessíveis on line, e ainda terem circulação em papel reduzida. 
Ao revisar a literatura sobre a Furna, é possível confirmar algumas impressões iniciais. Poucos trabalhos enfocam a sucessão de passagens humanas pelo abrigo, situando adequadamente o cemitério ou contextualizando os achados funerários e seu significado. Outro aspecto importante é a prática da utilização de códigos identificadores a partir do sistema em uso nos laboratórios de análises especializadas, sem a devida correlação com a identificação de origem arqueológica das amostras, o que impede que se possa fazer correlação adequada dos resultados com os achados originais e as referências da pesquisa arqueológica. Em tempos de discussão sobre ciência aberta, ainda que tenhamos ressalvas, seria muito mais adequado disponibilizar nos produtos científicos as informações e correlações necessárias que permitam o feed-back aos arqueólogos, e claro a realização de futuras e necessárias metanálises. Desta forma, e confirmando que tudo em ciência tem mão dupla, muitos dos trabalhos descrevem, classificam e discutem materiais provenientes do sítio mas pouco relacionam seus resultados com as interpretações já existentes sobre o grupo, a ocupação ou outros conhecimentos ou hipóteses arqueológicas desenvolvidas, permanecendo como informações pouco integradas à teia do conhecimento.

Alguns trabalhos publicados pela própria Jeannette Lima (Lima, 1985b; 1985c; 1991; Lima e Barbosa, 1997) sobre o sítio analisado em seu conjunto, somam-se à contribuição de Canto, cuja Dissertaçâo de Mestrado foi depois apresentada em evento cientifico (Canto, 1998; 1999). Mais tardiamente, Schmitz (Schmitz, 2014), após publicar o material original de Jeannette Lima, e tendo recuperando 
suas próprias notas pessoais sobre a escavação de 1987 da qual participara, publicou também sua síntese sobre a Furna do Estrago, apoiada em fotografias de sepultamentos e outros documentos. Rica em informações sobre os sepultamentos que ajudou a escavar e descrever sistematicamente, esta publicação oferece leitura metódica das sucessivas camadas depositadas no abrigo procurando reunir as evidências e dar-lhes um sentido, relacionando aspectos ambientais, as evidências arqueológicas de diferentes naturezas e o uso daquele espaço ao longo do tempo. Ao trazer sua interpretação, traz também algum contraditório que certamente deverá ser tema de aprofundamentos futuros.

A maior parte da literatura, entretanto, apenas refere sumariamente e protocolarmente características gerais da região e do sítio, e mesmo estas nem sempre utilizadas na discussão dos resultados. Em alguns casos mesmo os dados funerários não representam a informação mais atualizada disponível na data da publicação, possivelmente pela dificuldade de acesso à produção científica. $\mathrm{O}$ resultado, para o leitor que entra em contato pela primeira vez com a alguns trabalhos sobre a Furna, é um painel fragmentado de resultados.

Uma boa revisão sobre o sítio, a atualização e integração dos dados e o nivelamento das informações sobre o sítio seria vantajosa, tanto para aprofundar a interpretação dos achados, como para propor novas questões e hipóteses, quer sobre o sítio como um todo, quer sobre o cemitério em especial. Cotejar os resultados de diferentes estudos, retornar às suas fontes para elucidar duvidas que 
as publicações ou resumos não esclarecem, revisitar dados na literatura cinza, integrar dados arqueológicos, antropológicos e outros, à semelhança do que vem sendo feito para outros locais e sítios arqueológicos além de estabelecer um novo patamar de estudos, fortaleceria as diferentes linhas de pesquisa originadas da pesquisa arqueológica na Furna do Estrago, à semelhança do que já vem sendo feito para outros sítios do Brasil, como o sambaqui de Cabeçuda, em Santa Catarina ou o sítio de Amourins, no Rio de Janeiro, tem sido exemplos (Gaspar et al., 2013).

O presente trabalho pretende estimular um novo Projeto Furna do Estrago, cuja realização em rede seria capaz de re-significar achados e avançar nos estudos deste sítio funerário, que possivelmente ainda tenha muito a contribuir para o conhecimento do povoamento pré-histórico do Nordeste do Brasil.

\section{REVENDO SUMARIAMENTE A LITERATURA}

Os primeiros textos sobre a Furna foram publicados logo a seguir das escavações iniciais (Mello e Alvim e Mendonça de Souza, 1984; Lima, 1984) no volume 6 da CLIO, revista da Universidade Federal de Pernambuco, em seu primeiro número da Série Arqueológica. Apesar de veiculados na forma de modestas notas prévias, os textos já continham informações importantes para caracterização do sítio, tais como indicações da distância cronológica entre o sepultamento de cinzas e os enterros primários no cemitério; da espessura da camada ocupada pelo cemitério e diferentes profundidades em que os sepultamentos haviam sido realizados; a 
diversidade do acompanhamento funerário e sua preservação. Naquelas notas já foram veiculadas as primeiras propostas interpretativas. Seguindo com a produção de sua Dissertaçao de Mestrado Jeannette Lima publicou sobre a área arqueológica e a Furna (Lima, 1985a; 1985b). Ao longo dessa mesma década iniciou-se os trabalhos de bioarqueologia estudando os esqueletos humanos (Mello e Alvim e Mendonça de Souza, 1983/1984; Mello e Alvim e Mendonça de Souza, 1984a; 1984b; 1985; Mendonça de Souza e Mello e Alvim, 1986), e o primeiro trabalho de paleoparasitologia em coprólitos retirados do cemitério da Furna (Ferreira et al., 1989).

A dissertação de mestrado de Jeannette (Lima, 1985c), principal produto do período, foi defendida e disponibilizada com detalhadas descrições do sítio, e do primeiro conjunto de esqueletos humanos referidos ao curto período de uso do sítio como cemitério. Chamava atenção os acompanhamentos funerários contendo diversos artefatos em material vegetal preservados, permitiram as primeiras aproximações arqueobotânicas e etnográficas detalhadas.

Ainda em 1998 é feita uma publicação sobre a alimentação na caatinga, baseada nos achados da Furna e em referenciais etnográficos (Lima, 1988), fortalecendo o paradigma do conhecimentos do ambiente a partir do qual os grupos locais teriam podido adaptar-se. Este tema voltaria a ser central na Tese defendida na Fiocruz (Mendonça de Souza, 1995) sobre o sítio, assim como na Tese da própria Jeannette Lima (Lima, 2001). 
Os anos 1990 talvez sejam tanto em termos quantitativos, quanto em termos qualitativos, os mais produtivos sobre a Furna. Jeannette Lima abriu o período com a interpretação do que considerou dois períodos diferentes de subsistência na região (Lima, 1991), um deles correspondente aos achados no cemitério, o outro, mais antigo, correspondente às passagens anteriores do homem por aquele sítio. Seguiram-se outras produções (Lima et al., 1991; Lima, 1992; Mello et al., 1999a; 1999b) com resultados de análises zooarqueológicas e fitoarqueológicas (denominação daquela autora) sobre a Furna, e também a de Lima e Nascimento (1992), discutindo os estudos de Arte Rupestre em Pernambuco. Um número expressivo de contribuições veio também dos estudos bioarqueológicos que contribuíram com publicações sobre os esqueletos do cemitério (Mello e Alvim e Mendonça de Souza, 1990; Mello e Alvim, 1991; Mendonça de Souza e Mello e Alvim, 1992; Mendonça de Souza, 1992; Carvalho, 1992), e ainda comunicações e Dissertações de Mestrado, que abordavam principalmente aqueles remanescentes humanos analisando aspectos da sua morfologia normal (Salles, 1993), e das anomalias de desenvolvimento dos ossos daqueles indivíduos (Carvalho, 1995) e aspectos diferentes da saúde oral de crianças e adultos do grupo sepultado na Furna (Rodriges, 1996; 1997). O trabalho de paleoparasitologia estudou a presença de endoparasitos em algumas dezenas de coprólitos de animais e humanos retirados durante as escavações (Duarte, 1994), trouxe subsídios interessantes sobre as condições de homens e animais do período de uso da Furna como cemitério, ainda que parte das amostras não pudesse ter sido precisamente contextualizada na estratigrafia do sítio. 
O legado desta produção, foram frutíferos e interessantes resultados. A comprovação da escassez de ovos de parasitos em coprólitos humanos, em contraste com sua abundância nos coprólitos de fauna recolhidos no mesmo local (Duarte, 1994), permitiu propor que as doenças parasitárias não estariam presentes de maneira importante, fortalecendo a hipótese adaptativa defendida anteriormente para o grupo do cemitério (Mendonça de Souza, 1995). Uma década depois estudos palinológicos dos mesmos coprólitos (Teixeira-Santos, 2014) confirmou a ingestão de plantas de ação farmacológica específica pelo mesmo grupo. O achado de uma proporção elevada de anomalias de desenvolvimento (Carvalho, 1992; 1995) e a morfologia craniana pouco variável do grupo (Mello e Alvim, 1991), bem como o levantamento dos traços descontínuos ou epigenéticos dos crânios do cemitério da Furna, e sua comparação com outros grupos pré-históricos e atuais do Brasil (Mello e Alvim e Mendonça de Souza, 1990), caracterizaram sua morfologia, permitindo aprofundar discussão sobre aspectos genéticos do grupo, e sugerir a grande proximidade genética entre os indivíduos ali sepultados.

A Tese deste período, reunindo diferentes aspectos dos estudos bioarqueológicos dos esqueletos sepultados no cemitério, levou a proposição de modelos patocenótico e biocultural para caracterizar o grupo, considerando a morfologia dos ossos e dentes, além de considerar suas implicações sobre a saúde e a adaptabilidade daqueles indivíduos ao ambiente semiárido (Mendonça de Souza, 1995). Embora não publicada na forma de artigo, foi amplamente divulgada, 
ajudando a ordenar e integrar dados biológicos, culturais e do ambiente para o conjunto escavado no cemitério. Também firmou novo ponto de partida para estudo do cemitério, propondo o uso da estratigrafia das sepulturas para diacronização de dados sobre saúde. Esta estratégia permitiu uma interpretação paleopepidemiológica, contribuindo para dar significado às frequências de anomalias de desenvolvimento, e foi depois confirmada pela datação de ossos humanos $(1860 \pm 50$ B.P. Beta 145954 Esqueleto FE-18; $1730 \pm 70$ B.P. Beta 149749 Esqueleto FE-87.23; $1610 \pm 70$ B.P. Beta 145955 Esqueleto FE-45).

A confirmação de uma sequência temporal para os enterros, e do intervalo aproximado de uso do cemitério ofereceu ponto de partida para novas interpretações, como a discussão sobre o uso do espaço funerário apresentada em congresso da Associação Latinoamericana de Antropologia Biológica - ALAB (Lima e Mendonça de Souza, 1994), no Rio de Janeiro. A localização espacial de alguns sepultamentos, associada à provável consanguinidade dos indivíduos, sugerida pela sua morfologia, fundamentou parte da interpretação arqueológica do sítio na Tese de sua descobridora (Lima, 2001). A hipótese da existência de agrupamentos familiares nos enterros foi retomada e valorizada por outros autores (Leite et al., 2014; Fontes, 2016), principalmente nesta última Dissertação, que revisou as anomalias de desenvolvimento do esqueleto axial no grupo sepultado na Furna do Estrago reforçando a importância da diacronia para a interpretação paleoepidemiológica. 
Ainda na década de 1990, enquanto seguiam outras publicações arqueológicas (Lima, 1991; 1992; 1999; Lima e Souza, 1994; Lima e Barbosa, 1997), foi realizado o primeiro estudo malacológico no material proveniente da Furna do Estrago (Carvalho, 1997). Outro destaque desta década foram os primeiros resultados de aDNA, ou de paleogenética humana, para o grupo sepultado na Furna, e os resultados mais uma vez surpreenderam, pelo achado de novos haplótipos humanos ainda não descritos na América para povos originários (Santos, 1996; Ribeiro-dos-Santos et al., 1996; Ribeiro-dos-Santos et al., 1997). Tal como outras descobertas, entretanto, os achados foram questionados e a presença destas variantes genética na América só foi aceita depois de sua publicação por autores internacionais em outras amostras atuais e pretéritas, ainda que deve ser lembrada esta importante contribuição dos estudos da Furna do Estrago também à genética humana e estudos microevolutivos.

Também foi desta década a publicação que interpretou o achado de esqueleto cremado e fragmentado, encontrado em grande lente de fogueira, estratigraficamente posicionada acima dos sepultamentos no cemitério (Mendonça de Souza et al., 1998), cuja datação em carvão feita no Smithsoniam Institution (1040 \pm 50 BP) balizou por algum tempo a cronologia estimada para o cemitério, cuja antiguidade, antes da datação de ossos humanos, era estimada em cerca de 2.000 anos. A descrição minuciosa dos ossos cremados e sua associação com os dados de campo, indicaram um procedimento funerário diferenciado, ainda não descrito no Brasil, e reforçou a hipótese de tratar-se de episódio único 
representando o uso posterior do abrigo, possivelmente por grupo diferente do cemitério mais antigo.

No seguimento dos trabalhos sobre a Furna, mas já na ausência de sua principal investigadora, foi feita a comunicação (Mendonça de Souza et al., 2003) e a publicação (Carvalho et al., 2003) de um sepultamento escavado em 1984, que destoava do conjunto do cemitério da Furna, apresentando características típicas de um enterro secundário, e por isso não se confundindo com os outros inúmeros casos de ossos dispersos por perturbações causadas pelos sucessivos enterros no espaço exíguo do abrigo. Tratava-se do esqueleto de um indivíduo adulto jovem e robusto, denominado FE-51, que apresentava cortes nas extremidades dos ossos longos indicativos de desarticulação e descarne. Sua morfologia craniana e dentária diferente do padrão já bem documentado para a Furna, e as indicações de manipulação intencional, levou a que este exemplar fosse mantido fora da série em estudo por orientação de Marília Alvim. Sua descrição, portanto, foi publicada apenas posteriormente. Outros dois sepultamentos encontrados durante as escavações de 1987, e localizados no mesmo alinhamento, na lateral sudoeste do piso do abrigo, também foram considerados secundários (Lima et al., 2012; Schmitz, 2014), mas ainda não foram publicados. Estes achados, juntamente com a cremação, colocam questões a serem melhor esclarecidas sobre padrões culturais em transição, sobre o uso do abrigo e possíveis relações com outros grupos. Voltando à abordagem mais geral do cemitério, enquanto sítio funerário no 
contexto regional, os dados sobre marcadores de identidade do cemitério são retomados contribuindo para a discussão do tema (Castro, 2009).

No mesmo período um conjunto de coprólitos foi revisado para macrorestos e microrestos de alimentos e evidências parasitológicas, para elaboração de uma monografia de graduação (Silva, 1996). Seus resultados causaram polêmica pelo relato de achado de falange humana em coprólito supostamente associado a um sepultamento, mas não chegaram a ser suficientemente analisados do ponto de vista da tafonomia cadavérica para exclusão de associação acidental. Finalmente, é desta década a dissertação que revisa a interpretação da constituição estratigráfica e geomorfológica do sítio (Canto, 1998; 1999), e também é apresentada (Barbosa e Lima, 1999) uma interpretação da estratigrafia pleistocênica observada nas escavações da Furna, infelizmente apenas localizada em resumo.

Nos anos seguintes, foi dado seguimento aos estudos paleoparasitológicos (Guerra et al., 2001; 2003), desdobrados a partir da Tese da autora (Guerra, 2002), os quais apresentaram mais dados sobre os coprólitos da Furna. Pouco antes outro trabalho (Tunala, 2000) revisara mais uma vez os coprólitos, confirmando a ausência de ovos de parasitos do gênero Enterobios (Duarte, 1995) em sua Tese. Outros autores realizando revisões de amostras estocadas de coprólitos também confirmaram tais resultados no bojo de estudos de grupos de sítios de diferentes tipos, o que fez com que os surpreendentes resultados parasitológicos negativos 
do material da Furna fossem reconfirmados em diferentes análises e desse modo reforçados. Neste período já começava a circular entre os pesquisadores mais envolvidos com estudos da Furna, a versão prévia da tese de Jeannette (Lima, 2001), permitindo aprofundamento das questões colocadas por aquela autora, senão para o sítio como um todo, pelo menos para o cemitério. Na transição que impediu Jeannette de concluir seus estudos, permaneceu este legado inconcluso. Uma comunicação do período, contendo dados de paleogenética, foi feita ainda no início da mesma década, contando ainda com a co-autoria de Jeannette Lima, já in memoriam (Ribeiro-dos-Santos et al., 2003).

Foi também nesta década que os modelos patocenótico e biocultural (Mendonça de Souza, 1995) para a saúde e adaptabilidade do grupo no cemitério da Furna foi discutido no nível internacional (Mendonça de Souza e Carvalho, 2004). Estes modelos, válidos ainda hoje, foram ajustados com as contribuições posteriores, tendo servido de eixo estruturante das interpretações sobre o grupo que utilizou a Furna como cemitério, e ainda pode orientar perguntas e hipóteses a serem investigadas no futuro.

Destoando de certo modo com o predomínio de estudos de materiais biológicos, neste período foram realizadas duas comunicações sobre aspectos da cultura material sítio. Uma delas, sobre cerâmica (Moraes et al., 2004) e outra sobre o uso de sementes na confecção de adornos (Menezes, 2006). Enquanto no segundo trabalho os materiais analisados são oriundos das estruturas funerárias, no 
primeiro, o trabalho proposto é sobre a escassa cerâmica encontrada principalmente nos níveis superiores do piso do abrigo. Ainda que o tema cerâmica seja interessante, pois este tipo de artefato está ausente dos sepultamentos, exceto por raros fragmentos (Schmitz, 2014), sua investigação mais minuciosa poderá confirmar se ocorre apenas associada de fato a passagens tardias de grupos ceramistas pelo abrigo.

Chama atenção ainda no período a Dissertação de Mestrado, sobre macrorestos vegetais recuperados naquele sítio (Menezes, 2006), que aprofunda discussão sobre este tipo de evidência, e as associa aos dados paleopatológicos já divulgados anteriormente (Mendonça de Souza, 1995), relacionando as condições patológicas descritas com tipos de vegetais identificados no sítio, pelo seu poder medicinal. Este tema seria retomado quase 10 anos depois em uma tese de doutorado baseada no estudo paleopalinológico de coprólitos da Furna (Teixeira-Santos et al., 2015). Além de tentar associar os estudos de restos vegetais aos estudos de paleopatologia, a dissertação problematizou os dados arqueológicos existentes, devido à intensidade do uso do espaço do abrigo em diferentes momentos e problemas daí decorrentes para a interpretação arqueológica, chamando atenção para a importância da diacronização do uso do cemitério (Mendonça de Souza, 1995; Lima, 2001). Ainda deste período, pródigo em produções acadêmicas sobre a Furna, outra dissertação de mestrado (Santos, 2006) apresentou em sua Dissertação questões relacionadas à tafonomia de restos de fauna reptiliana. Outra publicação, sobre diagnósticos diferenciais entre paleopatologias e 
pseudopaleopatologias, nos remanescentes humanos da Furna do Estrago, (Carvalho et al., 2007), retoma os desafios diagnósticos, nem todos resolvidos no material estudado.

A década seguinte, na qual ainda nos encontramos, teve certamente contribuição importante com a publicação por Pedro Ignácio Schmitz, de um conjunto de textos e informações extraídas da Dissertação de Mestrado e do manuscrito da Tese de Doutoramento de Jeannette Lima. Com este material foi composta a síntese do estado da arte sobre a Furna deixada por aquela arqueóloga (Lima et al., 2012). Este trabalho, entretanto, não deve ser confundido com a Dissertação de Mestrado defendida na Universidade Federal de Pernambuco, sobre arqueologia funerária do mesmo sítio arqueológico, e aqui também referida, de outra autora com o mesmo sobrenome, também voltado para arqueologia funerária, discutindo morte e gênero (Lima, 2012), discussão iniciada em trabalho anterior (Lima e Castro, 2010). Ainda do mesmo período, outra publicação sobre abrigos funerários utiliza dados da Furna (Leite et al., 2014), aprofundando a descrição do cemitério, reforçando algumas questões específicas e reproduzindo várias informações já publicadas, entre elas as datações disponíveis para os ossos humanos. Neste trabalho, a questão da diacronização do cemitério também foi valorizada, sendo lembrado que a semelhança morfológica, a proximidade biológica e as prováveis relações de parentesco entre indivíduos sepultados no mesmo período e em conjuntos próximos, já haviam sido destacadas anteriormente (Lima e Mendonça de Souza, 1994; Lima, 2001). Apoiando-se em dados publicados, as autoras 
reforçam a interpretação de que o cemitério havia permanecido em uso pelo mesmo grupo de maneira continua, ressaltando aquele cemitério enquanto exemplo de local dedicado à preservação de remanescentes humanos, mas também de identidade coletiva e memória social, apoiadas na continuidade de práticas funerárias (Leite et al., 2014).

Outra contribuição deste período, retornando ao campo da paleoparasitologia de fauna da Furna, vem do grupo da Fiocruz, aportando novos dados (Sianto et al., 2012; Sianto et al., 2016). Ainda no campo da biomedicina, um grupo de neurologistas e neurocirurgiões (Vidal et al., 2013), publicou seu artigo em que discutem, com argumentos históricos e antropológicos, o padrão de crânios popularmente chamados de cabeças chatas, associando-os à extrema braquicrania dos esqueletos provenientes do cemitério da Furna do Estrago (Mello e Alvim e Mendonça de Souza, 1984; Mello e Alvim, 1991), e confirmando sua origem autóctone.

Neste período também foi publicada a síntese das observações e interpretações pessoais de Pedro Ignácio Schmitz, que participara das escavações de 1987 (Schmitz, 2014). Com base em seu diário e documentação de campo, apresentou sua interpretação da Furna e seus achados. Incluindo também menção à forma como o sítio foi descoberto e as etapas da pesquisa anteriores, o autor apresenta uma bem organizada e justificada interpretação da sucessão de ocupações e formação do testemunho arqueológico, incluindo aspectos paleoambientais, zooarqueológicos, arqueobotânicos relacionados às diferentes camadas 
estratigráficas e evidências da passagem de grupos pré-históricos no abrigo. A discussão do cemitério e seus testemunhos incluem descrição individual dos sepultamentos cuja escavação havia registrado em seu diário de campo. Aqui é necessário assinalar algumas divergências de interpretação sobre o sítio, por exemplo, em relação ao achados de sepultamentos secundários e à presença de fragmentos de cerâmica no sítio. Parte destes contraditórios, esperados em um material tão rico quanto o da Furna, certamente motivam futuras releituras e estudos mais detalhados.

Um dos últimos trabalhos da década foi de paleopalinologia (Teixeira-Santos et al., 2015), baseado na tese da primeira autora (Teixeira-Santos, 2014), onde a partir da análise de alguns exemplares de coprólitos coletados em contexto funerário bem definido, ou seja, anatomicamente relacionados a esqueletos humanos específicos, se confirmou a presença expressiva de polens de espécies vegetais de valor farmacológico, e sua possível relação com a saúde. Outro estudo bioarqueológico do período foi a Dissertação de Mestrado realizada na Universidade Federal de Pernambuco, detalhando as modificações e remodelações articulares nos esqueletos de jovens sepultados no cemitério da Furna (Alencar, 2015). No ano seguinte, outra Dissertação de Mestrado (Fontes, 2016), aprofundou a discussão e classificação das anomalias congênitas do esqueleto axial, já publicadas anteriormente, reforçando a importância da diacronização do cemitério na interpretação do achado e retornando a interpretação paleoepidemiológica das anomalias. Contribuindo com detalhamento da descrição 
e distribuição dos esqueletos com anomalias nos três períodos de sepultamento, reforçou os resultados anteriores. Este trabalho, entre aqueles encontrados na literatura, é um dos que melhor dialoga com as publicações mais densas sobre a Furna, fato este extremamente positivo.

A elaboração de uma síntese de dados que atualize e integre os dados produzidos sobre este sítio, e em especial sobre o seu cemitério, ainda deve ser feita, na medida em que a anterior, realizada para a Tese de Jeannete Lima, não incorporou produtos mais recentes. Este objetivo também não seria o da publicação feita para devolver à comunidade científica informações retidas na Tese inconclusa e não publicada antes de 2012. É trabalho por fazer.

Encerrando esta revisita à literatura, deve ser citada uma das poucas propostas de debruçar-se sobre a cultura material do sítio, que analisa a arte de trançar, comparando os achados da Furna a outro sítio onde este tipo de material está presente, o sítio de Alcobaça (Costa e Lima, 2016).

Certamente algumas contribuições ficaram fora do alcance desta revisão. Entretando os trabalhos comentados já dão ideia dos campos mais e menos explorados da temática da Furna, ajudando a visualizar parte das lacunas de conhecimento que certamente motiva a retomar pesquisas. 


\section{QUESTIONAMENTOS EM PESQUISAS ARQUEOLÓGICAS SOBRE CEMITÉRIOS}

Arqueologia é a ciência de ler e interpretar indícios da existência humana em lugares específicos, para ela e por ela o conhecimento, mas também a observação e a imaginação são essenciais. Sob o exercício metódico, sistemático e paciente das buscas e descobertas a imaginação, aliada da observação, levam a perguntar continuamente. A desafiar a complexidade dos processos acumulativos e intrincados que tornam funerais em estruturas arqueológicas a serem decifradas.

Um lugar de mortos (Mendonça de Souza et al., 2013) tem grande potencial bioarqueológico. Um lugar onde permanecem restos biológicos de corpos humanos deve ser estudado sob as mais diversas dimensões, e os dados biológicos e culturais dialogam. Onde corpos ou outros remanescentes diretos foram depositados, sepultados ou simplesmente abandonados, é possível resgatar evidências de diferentes naturezas, e por isso mesmo, seu estudo deve ser generosamente interdisciplinar. Devemos considerar hipóteses sobre a formação do testemunho, e planejar a melhor forma de abordá-lo, pois os mortos formam o sítio, assim como o sítio conformam os mortos. Por esta razão ir além dos ossos, por isso é arqueológico e bioarqueológico, é biocultural.

Qualquer situação de deposição testemunha também um processo local de transformação ao longo do tempo, que é contínuo, permanente e associa fatores antrópicos, bióticos e abióticos. As transformações afetam tanto o depositado quanto o terreno de deposição, exigindo leitura atenta e capaz de integrar os 
indícios deposicionais e de remoção/perturbação das evidências. E como o testemunho é indiciário, devemos ser ainda mais capazes de formular perguntas, já que pouco achamos, se não procuramos. A interpretação, por outro lado, deve disciplinadamente retroceder no tempo, reconstituindo os processos em ordem inversa à de sua ocorrência, portanto. Deixar de coletar informações ou evidências numa escavação feita há décadas, como apontam alguns trabalhos, foi erro do passado. Deixar de fazer perguntas que recuperem mais informações do acervo é um erro do presente.

Lugares guardam vestígios de natureza física, química, ou biológica dos seres, materiais e eventos passados. Nesse aspecto o piso da Furna do Estrago, apresentou condições micro-ambientais favoráveis à preservação arqueológica de evidências que em geral se preservam mal em nosso país, no entretanto, a preservação é variável, mesmo naquele sitio privilegiado. Os vestígios químicos, físicos, biológicos podem ser registrados em distintas escalas, e recuperados pelo uso de técnicas e métodos adequados, mas também pela formulação de novas perguntas e pela aplicação de novos olhares, vale a pena revisitar. Documentos como fotografias, desenhos e cadernos de campo podem portar informações antes não percebidas ou valorizadas, e podem trazer novas questões a partir da sistematização dos dados e da análise de hipóteses e resultados anteriores.

$\mathrm{Na}$ eventualidade de novas intervenções em testemunhos remanescentes de sítios arqueológicos é possível planejar abordagens novas e mais estratégicas tais como 
vem sendo preconizado na literatura (Gaspar e Mendonça de Souza, 2013). Novos olhares, novas perguntas, novas técnicas e métodos revigoram velhos materiais, metanálises podem mudar substancialmente interpretações. Acervos de pesquisas arqueológicas devem ser periodicamente revisitados, em busca de mais e melhores resultados. A Furna tem motivado estas visitas, como prova a literatura que continua a ser produzida após mais de 30 anos das primeiras publicações, confirmando que este sítio ainda guarda grande potencial.

Por outro lado, a reunião, sistematização e disponibilização dos dados produzidos sobre um sítio como a Furna do Estrago, também se faz necessário. O resultado de pesquisas e os dados e interpretações, assim como a documentação produzida, encontram-se dispersos por diferentes instituições e veículos, sendo de reunião trabalhosa. Em arqueologia brasileira, a dificuldade representada pela dispersão da produção científica, sua irregularidade, pouca acessibilidade, entre outros fatores torna a perda de informação e a descontinuidade de ideias uma barreira a mais na produção do conhecimento. O levantamento da literatura no presente artigo pode ser um ponto de partida para uma base de informações sobre a Furna. Ainda que não tenha sido objeto do trabalho a síntese das informações contidas na literatura, a reunião dos títulos ajuda a organizar e acessar a base de informações antes de partir para novos estudos.

Por outro lado, ao rever o que tem sido produzido, começam a delinear-se algumas questões que, salvo perda de alguma contribuição, não se encontram 
resolvidas, ou merecem aprofundamento na Furna do Estrago. Algumas destas não são novas, mas persistem por longo tempo. A sua apresentação deve ser entendida como contribuição a uma ciência indiciária, que deve ser continuamente tensionada.

Datas e ocupações antigas, diferentes passagens humanas, diferentes usos do mesmo abrigo, arte rupestre: a Furna do Estrago recebeu poucas publicações que discutiram o sítio como um todo, e a maior parte destas foi feita nos primeiros anos da pesquisa. Ainda que as publicações de Lima et al. (2012) e Schmitz (2014) recuperem e sintetizem dados sobre o sítio, pode ser o momento de produzir novas informações a partir da aplicação de novos métodos e técnicas a materiais coletados ou aos perfis remanescentes no sítio, por exemplo. Uma questão a ser detalhada seria o processo de formação do piso do abrigo, a origem dos depósitos de sedimentos existentes e suas relações com os processos naturais e antrópicos, a partir de uma abordagem geoarqueológica. Mais conhecimento sobre o processo de formação do piso e sua relação com a dinâmica do uso tardio e intensivo do sítio como cemitério seria importante.

A análise do solo do abrigo permitiria dialogar com a presença e conservação dos materiais no subsolo, mas também seu comportamento fora do sítio, em especial quando exposto a um ambiente radicalmente diferente do seu depósito original. Durante as primeiras análises osteológicas feitas em Recife, foi possível observar que a impregnação de alguns esqueletos conferia características higroscópicas, 
prejudiciais à sua conservação, como discutido por Jeannette Lima e esta autora. A conservação diferencial no sítio poderia, por sua vez explicar diferenças na presença, por exemplo, de acompanhamentos funerários, itens importantes para a caracterização cultural do cemitério, por exemplo.

Outras análises também pouco aparecem na literatura. Sobre os materiais líticos provenientes do abrigo, por exemplo. Feitas, poderiam aumentar o conhecimento sobre procedência de materiais, matérias primas, sobre tecnologias líticas. Outro tema, a análise da cerâmica, está apenas sinalizado em um resumo, teria sido completada? A cerâmica, de presença modesta no sítio, apesar disso é central a um contraditório: ausente como acompanhamento funerário, aparentemente seria material introduzido no abrigo em período tardio e posterior ao cemitério, mas o achado de fragmentos pequenos na base de dois sepultamentos justifica a hipótese de sua associação com os enterros, cujas covas, em uma das interpretações para o sítio, teriam sido abertas a partir do nível cerâmico. Que análises do material e dos registros de dados poderiam aprofundar esta discussão?

A arte rupestre, exposta e danificada pelo intemperismo e pela ação antrópica prolongada, como por exemplo o uso de fogo dentro do abrigo, poderia ser melhor documentada com técnicas modernas? A presença de vestígios de pictoglifos no teto do abrigo, a natureza dos pigmentos, e outros aspectos poderiam ser melhor conhecidos? 
Em relação ao cemitério, a literatura produzida privilegia, como esperado, a bioarqueologia, ainda que a busca pela interpretação de aspectos comportamentais como marcadores de identidade, os padrões dos enterros, e a distribuição temporal de materiais associados, tenham sido objeto de estudo. Entretanto, o número de trabalhos e o volume de dados produzidos sobre os ossos, dentes e coprólitos humanos foi provavelmente o maior e mais concentrado em um sítio arqueológico no Brasil. Estudos de outros materiais biológicos, como restos vegetais e de fauna, incluindo coprólitos de animais, complementam os dados. Materiais provenientes dos sepultamentos, mas também dos níveis correspondentes a outras passagens humanas pelo sítio, completam esta produção bioarqueológica, que representa a maior contribuição laboratorial ao conhecimento da Furna do Estrago. Mas apesar disto, este também não é um campo esgotado

Estudos paleonutricionais não chegaram a ser feitos, seriam muito úteis, principalmente se incluíssem análise de microevidências dos cálculos dentários, e também os isotópicos de estrôncio. A questão da nutrição poderia ser mais esclarecedora e rica, associando os materiais presentes no sítio, dados antropológicos e paleopatológicos e as informaçcões bioquímicas, e talvez o contato com o litoral possa estar representado também na mobilidade humana.

As hipóteses de coexistência, por algum tempo, de diferentes grupos, a sua associação ou fricção, a relação de contatos a distância e trocas culturais, além da mobilidade humana, foram pensadas e propostas em conversar e esboçadas 
apresentações, mas não aprofundadas. Quando durante seus estudos osteométricos Marília Alvim optou por excluir o esqueleto FE-51 da série, seu critério foi evitar enviesar os resultados, já que parecia fugir tanto ao padrão funerário (secundário, com sinais de desarticulação) quanto ao morfológico (crânio e ossos longos de aparência divergente). $\mathrm{O}$ achado de mais dois aparentes casos de sepultamentos secundários na campanha de 1987, sepultados em covas mais profundas, trouxe mais elementos a serem verificados, já que aquilo que poderia ser um enterro mais recente, intrusivo, e de outro padrão, torna-se agora mais provavelmente uma situação a ser melhor conhecida. O que significa a sua presença no cemitério? Variação de um padrão cultural do mesmo grupo? A presençca de outro grupo e sua influência ou incorporação de indivíduos? O padrão do FE-51 na preparação dos despojos repete-se nos outros dois?

Algumas perguntas demandam análises complementares e poderiam ser aprofundadas pois dialogam com outros elementos da arqueologia da Furna como a presença no sítio de materiais de origem distante, e as causas do crescimento dos indicadores de estresse aparentemente relacionado ao abandono do abrigo. A paleogenética não teve, e talvez não tenha, como responder precisamente sobre as relações entre estes indivíduos, por outro a associação biocultural poderá ajudar a propor hipóteses a serem tratadas com novas e mais potentes ferramentas, menos disponíveis na década de 1990. 
Os modelos patocenótico e biocultural para o grupo que sepultou na Furna também deveriam ser revisados, incorporando os dados produzidos depois. Um aspecto importante a ser revisto é a aparente contradição entre a potencialidade do Brejo que aparentemente mantinha seu potencial e disponibilidade de alimentos, e a proposta de estresse nutricional progressivo? Será possível evidenciar um ciclo curto de escassez que justifique abandono do sítio/aumento das lesões por estresse nutricional? Ou devemos explorar os dados que nos ajudem a elucidar aspectos dos contatos com novos ocupantes da região, cada vez mais atraente, por exemplo, para grupos horticultores? Este aspecto foi discutido anteriormente e sempre sugerido pela presença de padrões funerários secundários, da intercorrência mais recente de cremação, e da presença da cerâmica. Que outros indícios poderiam ser levantados em futuras modelagens sobre o grupo sepultado na Furna?

O número de indivíduos sepultados no período datado para o cemitério foi explorado num ensaio paleodemográfico antes das escavações de 1987, sugerindo taxa de crescimento baixa. Hoje, poderia ser melhor explorado para um conjunto maior de indivíduos e considerando novas abordagens constantes da literatura. Por outro lado, estudos de tafonomia cadavérica não chegaram a ser feitos, e a iconografia da Furna certamente contribuiria muito para esta revisita, que deveria ser complementada pelo cuidadoso inventário dos materiais para estabelecimento de Número Mínimo de Indivíduos a ser confrontado com o Número Real hoje considerado. Num sítio de enterros tão concentrados, as perdas e dispersão de ossos é esperada, e no caso, estão descritas tanto em campo quanto pelas 
antropólogas que trabalharam em laboratório: resta quantificar. Finalmente, a revisão de ossos de fauna, tal como tem sido observado em outros sítios, pode acrescentar ossos humanos imaturos a estimativa de mortos.

Finalmente, em relação aos funerais e seus padrões, a re-deposição, a distribuição espacial dos enterros e outros elementos certamente trarão novas interpretações e hipóteses a serem exploradas.

\section{RECOMENDAÇÃO FINAL}

O trabalho em rede, assim como o discurso obre ciência aberta está em moda. O fluxo de dados e ideia, não mais apenas nos colégios invisíveis tão caros aos estudiosos da ciência da informação, mas em pre-prints e espaços especiais de publicações científicas disponibilizados on line para maior troca de materiais informativos e foruns de discussão.

A Furna do Estrago, como outros sítios arqueológicos, demanda curadoria da grande quantidade de dados já produzidos sobre o sitio e seus materiais, muitos deles fora das instituições que abrigam o próprio acervo do sítio, cuja interlocução ainda é dificil. Curadoria de dados a qual sem dúvida é tão desafiadora para os pesquisadores quanto a análise exaustiva dos materiais recuperados em cada pesquisa. 
Nossos alunos seguem motivados com a produção de suas Dissertações e Teses, mas parte dos dados não dialogam suficientemente com a produção cientifica pertinente. Os problemas são vários, e especialmente, em contextos funerários como no caso do cemitério da Furna, as lacunas se abrem.

A Furna do Estrago parece ainda reclamar atenção e vale a pena investir. Para um sítio que assumiu seu destino turístico, parece ser possível também melhorar a translação do conhecimento.

Um projeto em rede, reunindo atores que produziram diferentes dados e interpretações sobre a Furna, numa proposta de produção coletivizada e solidária, seria potente e adequado para revisitar dados e materiais, não só funerários, mas do abrigo de cujas passagens humanas podemos saber provavelmente muito mais. Além disso seria um excelente laboratório para alunos que necessitam aprender mais sobre o desafio da interdisciplinaridade em sítios funerários.

\section{REFERÊNCIAS BIBLIOGRÁFICAS}

ALBUQUERQUE, M. 1971. "Nota prévia sobre a ocorrência de pictografias no Município de Brejo da Madre de Deus". Boletim do Instituto Joaquim Nabuco de Pesquisas Sociais 18: 107-134.

ALENCAR, R.O. de A. 2015. Estudo de osteoarqueologia das remodelações articulares nos adultos jovens inumados no cemitério pré-histórico da Furna do Estrago, Brejo da Madre de Deus, Pernambuco, Brasil. Dissertação de Mestrado, Universidade Federal de Pernambuco, Recife. 
BARBOSA, L.S. de S. e LIMA, J.M.D. de. 1999. Estratigrafia pleistocênica da Furna do Estrago. Recife: Anais do $8^{\circ}$ Congresso Nordestino de Ecologia - Repensando o Futuro.

CANTO, A.C. de L. 1998. Caracterização geoarqueológica e paleoambiental do sítio arqueológico Furna do Estrago, Brejo da Madre de Deus - PE/Brasil. Dissertação de Mestrado, Universidade Federal de Pernambuco, Recife.

CANTO, A.C. de L. 1999. Caracterização espacial do sítio arqueológico Furna do Estrago através de programas gráficos. Campinas: Anais do $25^{\circ}$ Congresso Brasileiro de Espeleologia.

CARVALHO, O.A. de. 1991. Espondilólise, espinha bífida oculta e variação numérica das vértebras nas colunas vertebrais da população pré-histórica do sítio Furna do Estrago, Brejo da Madre de Deus, Pernambuco. Rio de Janeiro: Resumos da $6^{\mathrm{a}}$ Reunião Científica da Sociedade de Arqueologia Brasileira.

CARVALHO, O.A. de. 1992. "Espondilólise e variações morfológicas congênitas identificadas na população pré-histórica do sítio Furna do Estrago, Pernambuco". Symposium 34 (2): 180-197.

CARVALHO, O.A. de. 1995. Análise das anomalias de desenvolvimento na população pré-histórica do sítio Furna do Estrago, Pernambuco, Brasil. Dissertação de Mestrado, Escola Nacional de Saude Pública Sergio Arouca/Fiocruz, Rio de Janeiro.

CARVALHO, O.A. de. 1996. "A presença dos mollusca (gastropoda) no sítio arqueológico Furna do Estrago, Brejo da Madre de Deus, PE, Brasil". Cadernos CCT da Unicap 1(I): 23-27.

CARVALHO, O.A. de; MENDONÇA. DE SOUZA, S.M.F.; QUEIROZ, A.N. de; SILVA, A.F. da; ALVES, M.A. de M. e SILVA, M.I.C. 2003. "Nota prévia sobre traços de desarticulação e descarnamento em um esqueleto do sítio arqueológico Furna do Estrago, Brejo da Madre de Deus, Pernambuco". Canindé 3: 293-297.

CARVALHO, O.A. de; QUEIROZ, A.N. de e MORAES, F.A. de A. 2007. "Diagnóstico diferencial entre fatores tafonômicos, anomalias de desenvolvimento e casos patológicos nos crânios exumados do sítio Furna do Estrago, Brejo da Madre de Deus, Pernambuco, Brasil". Canindé 10: 27-49. 
CASTRO, V.M.C. de. 2009. Marcadores de identidades coletivas no contexto funerário pré-histórico no Nordeste do Brasil. Tese de Doutorado, Universidade Federal de Pernambuco, Recife.

CISNEIROS, D. 2004. Práticas funerárias na pré-história do Nordeste do Brasil. Dissertação de Mestrado, Universidade Federal de Pernambuco, Recife.

COSTA, R.L. e LIMA, T.A. 2016. "A arte e a técnica de trançar na pré-história de Pernambuco. A cestaria dos sítios Alcobaça e Furna do Estrago". CLIO 31(2): 102-152.

DA-GLORIA, P.T. NEVES, W.A. e HUBBE, M. (orgs.) 2017. Archaeological and paleontological research in Lagoa Santa. The quest for the first Americans. Cham: Springer. $401 \mathrm{p}$.

DUARTE, A.N. 1994. Estudo paleoparasitológico em coprólitos do sítio arqueológico da Furna do Estrago, município do Brejo da Madre de Deus, Pernambuco, Brasil. Dissertação de Mestrado, Universidade Federal Rural do Rio de Janeiro, Itaguaí.

FERREIRA, J.E. 1998. Sítios da Serra do Cachorro, Brejo da Madre de Deus/Pernambuco, Brasil: uma contribuição ao estudo da área arqueológica dos Cariris Velhos. Dissertação de Mestrado, Universidade Federal de Pernambuco, Recife.

FERREIRA, L.F.; ARAÚJO, A.; CONFALONIERI, U. e LIMA, J.M..D de. 1989. "Trichuris trichiura eggs in human coprolites from the archaeological site of "Furna do Estrago", Brejo da Madre de Deus, Pernambuco, Brazil". Memórias do Instituto Oswaldo Cruz 84 (4): 581.

FONTES, M. de S. 2016. Aplicabilidade e contribuições da paleogenética à arqueologia: o caso do sítio Furna do Estrago/PE. Dissertação de Mestrado, Universidade Federal de Sergipe, São Cristóvão.

GASPAR, M.D.; KLOKLER, D.; SCHEEL-YBERT, R. e BIANCHINI, G.F. 2013. "Sambaqui do Amourins: mesmo sítio, perspectivas diferentes. Arqueologia de um sambaqui 30 anos depois". Revista del Museo de Antropologia 6:7-20.

GASPAR, M.D. e MENDONÇA DE SOUZA, S.M.F. (orgs.). 2013. Abordagens estratégicas em sambaquis. Erechin: Habilis. 312p. 
GUERRA, R. de M.S.N. de C. 2002. Análise ecológica de ácaros associados a coprólitos provenientes do sítio arqueológico da Furna do Estrago, município do Brejo da Madre de Deus, Estado de Pernambuco, Brasil. Tese de Doutorado, Instituo Oswaldo Cruz/Fiocruz, Rio de Janeiro.

GUERRA, R. de M.S.N. de C.; DUARTE, A.N.; GAZETA, G.S.; FERREIRA, L.F. e SERRA-FREIRE, N.M. 2001. "Mites associated with coprolites from the archaeological site of Furna do Estrago, Pernambuco State, Brazil". Entomological Vectors 8: 463-479.

GUERRA, R. de M.S.N. de C.; GAZETA, G.S; AMORIN, M.; DUARTE, A.N. e SERRA-FREIRE, N.M. 2003. "Ecological analysis of acari recovered from coprolites from archaeological sites of Northeast Brazil". Memórias do Instituto Oswaldo Cruz 98: 181-191.

LEITE, M.N.; CASTRO, V.C. de e CISNEIROS, D. 2014. "Furna do Estrago, Brejo da Madre de Deus, PE: Reflexões sobre o lugar dos mortos na paisagem". FUMDHAMentos XI: 50-64.

LIMA, A.P.V.M. de A. 2006. Gestão do turismo no sítio arqueológico da Furna do Estrago: Brejo da Madre de Deus - PE. Dissertaçãao de Mestrado, Universidade Federal de Pernambuco, Recife.

LIMA, D.R. de e CASTRO, V.M.C. 2010. Indicadores de gênero na população préhistórica da Furna do Estrago. Resumos do I Encontro Regional da Sociedade de Arqueologia Brasileira.

LIMA, D.R. de. 2012. Sobre morte e gênero. Uma análise dos papéis de gênero no contexto funerário dos sítios Justino-SE e Furna do Estrago-PE. Dissertação de Mestrado, Universidade Federal de Pernambuco, Recife.

LIMA, D.R. de. 2012. "Sobre morte e gênero. Uma análise dos papéis de gênero no contexto funerário dos sítios Justino-SE e Furna do Estrago-PE". CLIO 27 (Serie Arqueológica): 1-9.

LIMA, J.M.D. de. 1984a. "Pesquisa arqueológica no município do Brejo da Madre de Deus - Pernambuco". Symposium 26 (1): 9-60. 
LIMA, J.M.D. de. 1985a. "Arqueologia da Furna do Estrago, Brejo da Madre de Deus PE". CLIO 6 (Serie Arqueológica, 1): 97-111.

LIMA, J.M.D. de. 1985b. "Arqueologia do Brejo da Madre de Deus, Pernambuco". CLIO 7 (Série Arqueológica, 2): 91-94.

LIMA, J.M.D. de. 1985c. Arqueologia da Furna do Estrago, Brejo da Madre de Deus, Pernambuco. Dissertação de Mestrado. Universidade Federal de Pernambuco, Recife.

LIMA, J.M.D. de. 1988. "Alimentação do homem pré-histórico na região da Caatinga". Revista de Arqueologia 5(1): 103-112.

LIMA, J.M.D. de. 1991. "Dois períodos de subsistência no Agreste Pernambucano: 9.000 e 2.000 A.P.". CLIO 4 (Série Arqueológica, nº extraordinário), Anais do I Simpósio de Pré-História do Nordeste Brasileiro: 57-61.

LIMA, J.M.D. de. 1992. "Estudos zoo e fitoarqueológicos em Pernambuco". Symposium 34 (2): 146-179.

LIMA, J.M.D. de. 1999. Adornos da população pré-histórica do sítio Furna do Estrago, Brejo da Madre de Deus, Pernambuco. Anais da X Reunião Científica da Sociedade de Arqueologia Brasileira, Recife: Ed. UFPE.

LIMA, J.M.D. de e BARBOSA, L.S.S. 1997. Formação e estratigrafia da Furna do Estrago, Brejo da Madre de Deus - PE. Recife: Resumos do I Seminário Regional de Ecodesenvolvimento. pp.88-89.

LIMA, J.M.D. de e MENDONÇA DE SOUZA, S.M.F. 1994. O uso do espaço no cemitério pré-histórico da Furna do Estrago: aspectos demográficos e sócio-culturais. Rio de Janeiro: Resumos do III Congresso da Associação Latinoamericana de Antropologia Biológica/ II Reunião da Sociedade Brasileira de Paleopatologia.

LIMA, J.M.D. de e NASCIMENTO, A.B. 1992. "A fragilidade dos estudos de arte rupestre em Pernambuco". Symposium 34 (2): 198-211.

LIMA, J.M.D. de; QUEIROZ, A.N.; CARVALHO, I.P. e CARVALHO, O.A. de. 1991. Resultados parciais da identificação dos restos alimentares resgatados no sítio 
arqueológico Furna do Estrago, Brejo da Madre de Deus, Pernambuco. Rio de Janeiro:

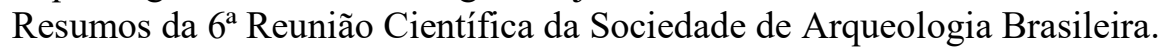

LIMA, J.M.D. de; SCHMITZ, P.I.; MENDONÇA DE SOUZA, S.M.F. e BEBER, M. V. (orgs.). 2012. "A Furna do Estrago no Brejo da Madre de Deus, PE". Pesquisas 69: 1151.

MARTIN, G. 1994. "Os rituais funerários na pré-história do Nordeste". CLIO 10: 29-45.

MELO, E.; BARBOSA, L.S.S. 1999. Quantificação de restos zooarqueológicos da Furna do Estrago. Recife: Resumos do $8^{\circ}$ Congresso Nordestino de Ecologia Repensando o Passado.

MELO, E.F.C.; BARBOSA, L.S.S. e LIMA, J.M.D. de. 1999b. Revisão, classificação e quantificação de restos zooarqueológicos da Furna do Estrago. Recife: Resumos da IX Semana de Estudos Docentes da Unicap.

MELO, E.F.C.; BARBOSA, L.S.S. e LIMA, J.M.D. de. 1999c. Quantificação de restos zooarqueológicos da Furna do Estrago. Recife: Atas do $8^{\circ}$ Congresso Nordestino de Ecologia - Repensando o Futuro.

MELLO E ALVIM, M.C. de. 1991. "O Grupo Pré-Histórico da Furna do Estrago e suas Relações Biológicas com Outras Populações Pré-Históricas e Atuais do Brasil". Clio (Serie Arqueológica 4 e Anais do I Simposio de Arqueologia do Nordeste): 81-83.

MELLO E ALVIM, M.C. de e MENDONÇA DE SOUZA, S.M.F. 1983/1984. "Os esqueletos da Furna do Estrago - Pernambuco, Brasil - Nota Prévia". Arquivos do Museu de História Natural VIII-IX: 349-363.

MELLO E ALVIM, M.C. de e MENDONÇA DE SOUZA, S.M.F. 1984a. "Os esqueletos humanos da Furna do Estrago, Brejo da Madre de Deus, Pernambuco, Brasil" - Nota Prévia. Symposium 26 (1): 61-86.

MELLO E ALVIM, M.C. de e MENDONÇA DE SOUZA, S.M.F. 1984b. "Os esqueletos humanos da Furna do Estrago, Brejo da Madre de Deus, Pernambuco, Brasil". CLIO 6 (Série Arqueológica 1): 95-98. 
MELlO E ALVIM, M.C. de e MENDONÇA DE SOUZA, S.M.F. 1985. Paleodemografia da população da Furna do Estrago, Pernambuco. Goiânia: Resumos da III Reunião Científica da Sociedade de Arqueologia Brasileira.

MELLO E ALVIM, M.C. de e MENDONÇA DE SOUZA, S.M.F. 1990. "Relações biológicas entre populações indígenas atuais e pré-históricas do Brasil". CLIO (Série Arqueológica) 1(6): 69-80.

MELLO E ALVIM, M.C. de e MENDONÇA DE SOUZA, S.M.F. 1991. "Relações biológicas entre populações indígenas pré-históricas e atuais do Brasil". Revista de Arqueologia 6: 136-143.

MENDONÇA DE SOUZA, S.M.F. 1992. "Lesões traumáticas como indicadores de atividades físicas na população da Furna do Estrago, Pernambuco, Brasil". In A. ARAÚJO e L.F. FERREIRA (coords.) Paleopatologia \& Paleoepidemiologia. Estudos Multidisciplinares. Rio de Janeiro: ENSP (Série Panorama 4). Pp. 123-140.

MENDONÇA DE SOUZA, S.M.F. 1995. Estresse, doença e adaptabilidade: Estudo comparativo de dois grupos pré-históricos. Tese de Doutorado, Escola Nacional de Saude Pública Sergio Arouca/Fiocruz, Rio de Janeiro.

MENDONÇA DE SOUZA, S.M.F. e CARVALHO, O.A. de. 1991. Lesões traumáticas e variações morfológicas congênitas em esqueletos pré-históricos: um estudo paleoepidemiológico. IV Jornada Científica. 70 Anos do Hospital Evandro Chagas, Fiocruz.

MENDONÇA DE SOUZA, S.M.F. e CARVALHO, C.R. 2004. A biocultural model to explain health and disease in Furna do Estrago, a Brazilian Savanna people. Tampa: Abstracts of the 31st Annual Meeting of the Paleopathology Association.

MENDONÇA DE SOUZA, S.M.F.; LIMA, J.M.D. de e CARVALHO, O.A. de. 1998. "Restos humanos calcinados: cremação em abrigo ou sepultamento de cinzas?". Revista de Arqueologia 11: 107-124.

MENDONÇA DE SOUZA, S.M.F. e MELlO E ALVIM, M.C. de. 1986. Paleodemografia da população da Furna do Estrago, Pernambuco. Goiânia: Resumos da III Reunião da Sociedade de Arqueologia Brasileira. 
MENDONÇA DE SOUZA, S.M.F. e MELLO E ALVIM, M.C. de. 1992. "A população pré-histórica da Furna do Estrago: adaptação humana ao Agreste Pernambucano". Symposium 34 (2): 123-145.

MENDONÇA DE SOUZA, S.M.F.; CARVALHO, O.A. de; QUEIROZ, A.N.; ALVES, M.A.de M.; SILVA, M.I.C. \& SILVA, A.F. 2003. Traços de desarticulação e descarne em esqueletos do sítio arqueológico da Furna do Estrago, Brejo da Madre de Deus, Pernambuco, Brasil. São Paulo: Resumos do XII Congresso da Sociedade de Arqueologia Brasileira.

MENDONÇA DE SOUZA, S.M.F.; WESOLOWSKI, V.; LESSA, A. e RODRIGUESCARVALHO, C. 2013. "Escavar e nterpretar lugares de deposição de mortos". In M-D. GASPAR, M.D. e S.M.F. MENDONÇA DE SOUZA (orgs.) Abordagens Estratégicas em Sambaquis. Erechin: Habilis. 312p.

MENEZES, A.V.A. 2004. A utilização de sementes em adornos funerários encontrados nos esqueletos humanos do sítio arqueológico Furna do Estrago, Brejo da Madre de Deus/PE, Brasil. Aracaju: Anais do $3^{\circ}$ Workshop Arqueológico de Xingó.

MENEZES, A.V.A. 2006. Estudo dos macrorrestos vegetais do sítio arqueológico Furna do Estrago, Brejo da Madre de Deus, Pernambuco, Brasil. Dissertação de Mestrado, Universidade Federal de Pernambuco, Recife.

MORAES, F.A. de A. 2004. Proposta de análise do material cerâmico do sítio Furna do Estrago, Brejo da Madre de Deus/PE, Brasil. Aracaju: Anais do $3^{\circ}$ Workshop Arqueológico de Xingó.

OLIVEIRA, M.M.B.M.; CASTRO, V.M.C. 2013. Estudo das práticas funerárias dos enterramentos infantis do sítio Furna do Estrago, Pernambuco. In: XXI Congresso de Iniciação Científica da UFPE, 2013, Recife. Anais do XXI Congresso de Iniciação Científica da UFPE.

OLIVEIRA, M.M.B.M.; CASTRO, V.M.C.; SILVA, S.F.S.M. 2015. Diferentes práticas funerárias no sítio pré-histórico Furna do Estrago, PE. In: I Simpósio Internacional Arqueologia de Engenhos e I Seminário de Arqueologia e Patrimônio Cultural de Pernambuco, 2015, Recife. Resumo do I Simpósio Internacional Arqueologia de Engenhos e I Seminário de Arqueologia e Patrimônio Cultural de Pernambuco. 
OLIVEIRA, R.; PROUS, A. e TOBIAS Jr., R. 2013. "A Bibliografia da Arqueologia Brasileira". Arquivos do Museu de História Natural da UFMG 22 (v.1, v.2)

RIBEIRO-DOS-SANTOS, A.K.C.; SANTOS, S.E.B.; MACHADO, A.L.; GUAPINDAIA, V. e ZAGO, M.A. 1996. "Heterogeneity of mitochondrial DNA haplotypes in pre-Columbian natives of the Amazon region". American Journal of Physical Anthropology 101: 29-37.

RIBEIRO-DOS-SANTOS, A.K.C. e SANTOS, A.C.F. dos. 2002. "Análise do Polimorfismo do mtDNA em um sítio arqueológico pré-Colombiano: Furna do Estrago PE". Abstracts of the 47th National Congress of Genetics, Brazilian Journal of Genetics (supl.): v.1.

RIBEIRO-DOS-SANTOS, A.K.C.; SANTOS, A.C.F. dos; AMAZONAS, K.;

LIMA, J.M.D. de (in memoriam); MENDONÇA DE SOUZA, S.M.F. e SANTOS, S.E. 2003. "Heterogeneidade do DNA ancestral da população da Furna do Estrago, Pernambuco". Resumos do IX Congresso da Sociedade de Arqueologia Brasileira, São Paulo.

RODRIGUES, C.D. 1996. Paleopatologia dentária entre os remanescentes esqueletais do sítio arqueológico Furna do Estrago. Pernambuco, Brasil - Dados preliminares. Buenos Aires: Resumos do IV Congresso da Associação Latinoamericana de Antropologia Biológica/ Segunda Jornadas Nacionales de Antropologia Biológica.

RODRIGUES, C.D. 1997. Perfil dento-patológico nos remanescentes esqueletais de dois sítios pré-históricos brasileiros: o cemitério da Furna do Estrago (PE) e o sambaqui de Cabeçuda (SC). Dissertação de Mestrado, Escola Nacional de Saude Pública Sergio Arouca/Fiocruz, Rio de Janeiro.

SALLES, A.D. 1993. Estudo morfométrico de vértebras lombares e sua aplicação na análise da transmissão do peso corporal sobre a coluna lombar - estudo de casos de uma amostra esquelética de população indígena. Dissertação de Mestrado, Universidade Federal do Rio de Janeiro, Rio de Janeiro.

SANTOS, G.C. 2006. Estudo tafonômico da arqueofauna reptiliana do sítio Furna do Estrago, Brejo da Madre de Deus, Pernambuco, Brasil. Dissertação de Mestrado, Universidade Federal de Pernambuco, Recife. 
SANTOS, S.E.B.; RIBEIRO-DOS-SANTOS, A.K.C.; MEYER, D. e ZAGO, M.A. 1996. "Multiple founder haplotypes of mitochondrial DNA in Amerindians revealed by RFLPs and sequencing". Annals of Human Genetics 60: 305-319.

SCHMITZ, P.I. 2014. "Um grande sítio do Agreste Pernambucano: de volta à Furna do Estrago" CLIO 29(2): 31-56

SIANTO, L.; DUARTE, A.N.; CHAME, M.; MAGALHÃES, J.G.; SOUZA, M. e FERREIRA, L.F. 2012. "Trichuris sp.from $1040 \pm 50$-year-old cervidae coprolites from the archaeological site Furna do Estrago, Pernambuco, Brazil". Memórias do Instituto Oswaldo Cruz 107(2): 273-274.

SILVA, J.A.M. 1996. Análise paleopatológica e de restos alimentares em coprólitos humanos do sítio arqueológico Furna do Estrago - Brejo da Madre de Deus, Pernambuco. Monografia de Bacharelado, Universidade Federal Rural de Pernambuco, Recife.

TUNALA, E.G. 2000. Paleoepidemiologia da enterobíase humana: Revisão da literatura e reexame dos coprólitos da Furna do Estrago, Brejo da Madre de Deus, Pernambuco, Brasil. Monografia de Especialização, Escola Nacional de Saude Pública Sergio Arouca/Fiocruz, Rio de Janeiro.

TEIXEIRA-SANTOS, I. 2014. Alimentação de grupos humanos pré-históricos do sítio arqueológico Furna do Estrago, Pernambuco - Brasil: Um estudo em coprólitos. Tese de Doutorado, ENSP/Fiocruz, Rio de Janeiro.

TEIXEIRA-SANTOS, I.; SIANTO, L.; ARAUJO, A.; REINHARD, K.J. e CHAVES, S.A. de M. 2015. "The evidence of medicinal plants in human sediments from Furna do Estrago prehistoric site, Pernambuco State, Brazil". Quarternary International 377:112117.

VIDAL, C.H.F.; SILVA, J.C. da; LINS, C.J.P.; BRAINNER-LIMA, A.M. e VALENÇA, M.M. 2013. "Craniovertebral junction malformation in Northeastern Brazil: the Mith of the Dutch Colonization". Archives of Neuropsichiatry 71(6): 405-407. 